\title{
Determination of Projects Viability Using Capital Budget in the Local Government Areas in Ondo State Nigeria
}

\author{
Olurankinse Felix \\ Correspondence: Olurankinse Felix, Department of Accounting, Adekunle Ajasin University, Akungba Akoko \\ Ondo State Nigeria. E-mail: olurankinsefelix@yahoo.com
}

Received: September 14, 2012

Accepted: October 9, 2012

Online Published: November 7, 2012

doi:10.5539/ibr.v5n12p112

URL: http://dx.doi.org/10.5539/ibr.v5n12p112

\begin{abstract}
Government in Nigeria oftentimes embark on capital projects without giving due consideration to the need of the people to which the project serves. Most of these projects do not have economic and social values hence after completion they are either not fully utilized or are jettison along the line. The paper looks into some projects of the local governments in order to find out their levels of viability in terms of need, usage and acceptability to its immediate community. In doing this, four key capital projects were examined in six local governments within a period of five years (2006-2010). Data for this study were mainly secondary. Both correlation and regression matrix were used to analyze the data. The study reveals that Water provision is mostly needed by the people and hence should be given adequate priority by the government.
\end{abstract}

Keywords: capital project, capital budget, viability, local government

\section{Introduction}

The general concept of local government is that authority of power established in a locality by a central or state government with a view to achieve effective government at the grassroots level (Nwankwo, 2004). The need for this kind of government cannot be overemphasized as it exists to bring the federal government closer to the people and makes its impact felt in all the nooks and crannies of the areas (Durmck, 2002). This impact of government can only be felt through the execution of basic capital projects. The term capital means the funds employed to finance fixed and long term assets. Capital budgeting involves making investment decisions concerning the financing of capital projects by government. Making investment decisions that will better the life of the rural dwellers is very germane since funds are scarce and there is a need to spend wisely the available scarce financial resources. Over the years, projects are executed on a continuous basis, but the reality is that majority of these executed projects are not viable both in terms of usage or benefits and acceptability. Government in Nigeria executes projects based on their political party priority rather than considering the social and economic benefits to the ultimate users. No wonder why we have several of these projects though completed but yet abandoned or under utilized for lack of social and economic benefits or due to wrong location. This paper intends to take a cursory look into some of these projects in order to determine their viability and frequency of execution.

\section{Literature Review}

The World Bank institute (2008) classifies budgets into two broad categories. According to this body, a traditional form of budgeting consists of separate estimates of recurrent revenue and expenditures and capital spending. Capital expenditure according to Akpan (2005) is the cost of bringing to existence new institutions, infrastructures, services and projects. Capital expenditures as expressed by kwanashie (2000) are designed to provide new or additional governments facilities for public services. Expenditures on capital projects are designed to provide new or additional governments facilities for public services. Since the objective is to provide major public facilities that have a relatively long life within the limits of available public resources, capital budgeting should involve planning, programming and formulation of policies in terms of the desired levels of public service to be provided- goals and objectives. These goals and objectives should be related to population and economic levels and economic trends and projections to ascertain future demands for public services and facilities (Whyne, 2003).

The need for programming capital improvements arises from the limited fiscal resources available to any level of 
government and the need for government to perform its numerous tasks (Schwartz, 2008). Programming should be based on a system of priorities tied to the goals and objectives set forth in the planning phase. Planning reveals need; programming provides the basis for ordering the sequence in which these needs can be met most effectively. The financing phase relates to any analysis of the sources of funds to be drawn upon and how the payments are to be made. There are a number of ways in which capital facilities can be financed- on a "pay-as-you-go" basis that is, from current revenue, from capital reserve funds, from long term leasing, and through long-term or short-term borrowing. These methods must be evaluated in terms of the overall fiscal capacity and in the light of the particular capital improvements needs. Governments commonly establish a uniform and organized multi-year capital investment plan. According to the World Bank institute (2002), the capital budget process includes the following steps:

- Inventory of capital assets

- Developing of a capital investments

- Developing of multi-year investment plan; and

- Implementing the capital budget

The first step on the development of a capital budget is to take inventory and provide an assessment of the current condition of all infrastructural facilities. A systematic process for capital investment planning can be built around a very simple information base that confers the need for new or replacement infrastructure. The currency of services usually provides the platform for determining future investment spending. More detailed analysis of the level and quality of service should be carried out as part of specific capital project analysis. From this existing inventory of investment needs, government can examine the areas of greatest need with respect to existing infrastructure programmes and can add potential capital investment projects.

In developing the capital investment plan; it is important to establish goals for the level and quantity of service in terms of measurable indicators. The use of service goals as a motivational instrument underpinning the investment plan enables jurisdiction to determine whether infrastructure should be replaced, upgraded, or extended, or whether entirely new investment should be undertaken. The multi-year plan establishes the time schedule and costs to complete these projects in the recommended period. The benefits of multi-year horizon capital investment plan include:

- Assisting the government in programming scarce financial resources;

- Allowing the government the opportunity to select alternative cost-effective solutions; and

- Allowing the government to engage in prudent borrowing and other public debt policies.

A central element of the capital budget is the financial analysis aimed at minimizing the financial effect of investment project(s) on the budget, while maximizing the impact or returns of the project in addressing the need of the community. The capital budget process is not only a management tool for guiding the expenditure of public resources over an extended period of time, but also represent a commitment by the government to provide its community with the desired and required level of service (Omolehinwa, 2005). In financial planning the government should investigate the financing options and fiscal feasibility of funding the various project requests. The number of public investments that a government can finance generally depends on the following non-exclusive list

- The level of recurring future operating expenditures.

- The cost recovery elements for individual projects and potential for the public investment to be revenue generating.

- The availability of cost sharing through public/private partnership.

- Debt structures and instrument (debt carrying capacity).

\section{Methodology}

The population for this study comprises of the eighteen local governments from which a sample size of six local governments were randomly selected. Data were sourced directly from published materials, which include annual financial statements and publication of approved budget estimates for the period under study. The six local governments selected are:

Ondo West

NDW

Idanre

IDR 


\section{Akoko North West AKNW \\ Owo WWW \\ Okitipupa KTP \\ Odigbo DGB}

\section{Results and Discussion}

The analysis was done with the use of correlation and regression matrix using four key capital projects. The four projects are Water provision (VWP), Health facilities (VHF), School buildings (VSB) and Agricultural inputs (VAI).

\subsection{Model Specification}

The model is specified as follows:

$\mathrm{CBit}=\mathrm{F}($ VAIit, VWPit, VSBit, VHF $)$ and it is expressed exclusively as

$$
C B i t=(\alpha o+\alpha 1 V A I i t+\alpha 2 V W P i t+\alpha 3 V S B i t+\alpha 4 V H V i t+U t)
$$

$\mathrm{U}=$ Stochastic (random) error term

$\mathrm{I}=1,2,3$. $.6=6$ local government areas

$\mathrm{t}=$ time

$\mathrm{CB}=$ Capital Budget

Other variables are as previously defined.

Table 1. Capital Budgeted and Capital Spending in Ondo West Local Government

\begin{tabular}{llllll}
\hline YEARS & CB(N) & VAI(N) & VWP(N) & VSB(N) & VHF(N) \\
\hline 2006 & $85,880,970$ & 644,250 & $18846528-75$ & $(111,729-75)$ & $645,1449-75$ \\
2007 & $90,188,405-25$ & $846,7221-75$ & $29117564-25$ & $(2,003,110-5)$ & $16,563,456$ \\
2008 & $110,705,016$ & $101,212,5$ & $66137139-75$ & $(1,353,000)$ & $5,060,250$ \\
2009 & $167,535,552$ & 27,000 & $104,408,828-25$ & $(6794250)$ & $10,543,920-75$ \\
2010 & $248,482,292-3$ & $9158812-5$ & $228,246,102$ & - & $9,199,195-5$ \\
TOTAL & $702,792,235-6$ & $19,309,409-25$ & $446,756,163$ & $(10,262,090-25)$ & $47,818,272$ \\
\hline
\end{tabular}

Source: Annual financial statements.

Table 2. Capital Budgeted and Capital Spending in Idanre Local Government

\begin{tabular}{llllll}
\hline YEARS & CB(N) & VAI(N) & VWP(N) & VSB(N) & VHF(N) \\
\hline 2006 & $14,904,750$ & $1,095,000$ & $18,690,441-75$ & - & $4,809,750$ \\
2007 & $82,800,000$ & 457,527 & $55,002,697-5$ & $32,910,220-5$ & $1,487,013-75$ \\
2008 & $41,044,444-5$ & 33,750 & $29,992,611-75$ & $2,910,373,373$ & $1,614,304-5$ \\
2009 & $19,125,000$ & $188,2,500$ & $26,941,462-5$ & $1,080,561$ & $2,872,555-5$ \\
2010 & $403,500,000$ & $4,497,900-75$ & $167,236,792-50$ & $779,092-5$ & $2,115,061-5$ \\
TOTAL & $561,374,194-5$ & $7,966,677-75$ & $297,864,006$ & $37,694,247$ & $12,898,685-25$ \\
\hline
\end{tabular}

Source: Annual financial statements.

Table 3. Capital Budgeted and Capital Spending in Akoko North West Local Government

\begin{tabular}{llllll}
\hline YEARS & CB(N) & VAI(N) & VWP(N) & VSB(N) & VHF(N) \\
\hline 2006 & $17,625,000$ & $50,550-75$ & $13,446,750$ & $(2,250,000)$ & - \\
2007 & $91,500,000$ & - & $1,624,875$ & $(19,152,535-5)$ & $9,207,247-5$ \\
2008 & $99,091,125$ & - & $2,790,840$ & 19339875 & $8,332,875$ \\
2009 & $167,659,530$ & $1,314,372-75$ & $51,143,816-25$ & $(15,960,241-5)$ & $6,244,500$ \\
2010 & $337,762,500$ & $132,887-25$ & $139,454,650-5$ & $(278,144,67-75$ & $11,536,107-75$ \\
TOTAL & $713,638,155$ & $1,497,810-75$ & $5,271,698,741$ & $(45,837,387-75)$ & $35,320,730-25$ \\
\hline
\end{tabular}

Source: Annual financial statements. 
Table 4. Capital Budgeted and Capital Spending in Okitipupa Local Government

\begin{tabular}{llllll}
\hline YEARS & CB(N) & VAI(N) & VWP(N) & VSB(N) & VHF(N) \\
\hline 2006 & $47,596,000-5$ & - & $7,086,750$ & $(37,854,529-5)$ & $6,565,671.75$ \\
2007 & $134,459,016-75$ & $1,321,500$ & $6,750,000$ & $27,350,333-25)$ & $4,215,469.5$ \\
2008 & $200,625,000$ & - & $20,120,655-75$ & $(38,795,755-5)$ & $6,859,552.5$ \\
2009 & $398,587,500$ & $26,250,000$ & $132,092,132-25$ & $(60,232,500)$ & $3,131,850$ \\
2010 & $455,152,212-5$ & - & $253,714,233-75$ & - & - \\
TOTAL & $1,236,419,730$ & $39,456,000$ & $419,763,771-7$ & $(164,233,118-3)$ & $20,772,543.75$ \\
\hline
\end{tabular}

Source: Annual financial statements.

Table 5. Capital Budgeted and Capital Spending in Owo Local Government

\begin{tabular}{llllll}
\hline YEARS & CB(N) & VAI $(\mathrm{N})$ & VWP(N) & VSB(N) & VHF(N) \\
\hline 2006 & $9,450,000$ & $3,686,406$ & $6,041,220$ & $8,070,971-25$ & $6,349,041$ \\
2007 & $9,450,000$ & $3,453,848-25$ & $7,768,624-4$ & $4,076,144-25$ & $9,478,500$ \\
2008 & $18,931,713-75$ & $3,214,296-75$ & $3,953,111-25$ & $(2,261,250)$ & $8,687,811-75$ \\
2009 & $55,875,000$ & $32,413,309-5$ & $34,427,151$ & $(431,178-25)$ & $13,456,635-75$ \\
2010 & $42,375,000$ & 562,500 & $2,675,990-25$ & $(7,500,000)$ & $4,017,591-75$ \\
TOTAL & $136,081,713-8$ & $13,330,360-5$ & $54,866,097$ & $2,339,687-25$ & $41,989,580-25$ \\
\hline
\end{tabular}

Source: Annual financial statements.

Table 6. Capital Budgeted and Capital Spending in Odigbo Local Government

\begin{tabular}{llllll}
\hline YEARS & CB(N) & VAI $(N)$ & VWP(N) & VSB(N) & VHF(N) \\
\hline 2006 & $46,087,500$ & - & $13,682,812-5$ & $(3,560,437-5)$ & $4,970,559-75$ \\
2007 & $128,462,445-75$ & $8,278,278$ & $77,233,581-75$ & $(4,643,319-75$ & $6,943,476$ \\
2008 & $112,875,000$ & $2,394,000$ & $135,194,101$ & $(12,610,851)$ & $6,058,791-75$ \\
2009 & $113,625,000$ & $1,462,500$ & $14,437,500$ & $(13,027,378-5)$ & $9,061,800$ \\
2010 & $338,160,750$ & $57,187,500$ & $258,984,414$ & $(8,013,757-3)$ & $57,498,193-5$ \\
TOTAL & $630,947,520-7$ & $69,322,278$ & $499,532,318-3$ & $41,855,744-25$ & $84,532,821$ \\
\hline
\end{tabular}

Source: Annual financial statements.

\subsection{Correlation Analysis of Variables}

Correlation analysis presents a pictorial view of the degree and existence of relationship between two variables. In this study five variables are involved for each local government. These are Capital Budget (CB), value of Agricultural inputs (VAI), values of Water provision (VWP), value of School buildings (VSB) and value of Health facilities (VHF). The result of correlation analysis among the variables for each local government is presented as follows.

Table 7. Correlation Matrix for Ondo west (NDW)

\begin{tabular}{llllll}
\hline & CB & VAI & VWP & VSB & VHF \\
\hline CB & 1.0000 & & & & \\
VAI & 0.6424 & 1.0000 & & & \\
VWP & 0.9505 & 0.6479 & 1.0000 & 1.0000 & 1.0000 \\
VSB & -0.3622 & 0.3128 & -0.315 & 0.1257 & \\
VHF & 0.7145 & 0.7272 & 0.5390 & & \\
\hline
\end{tabular}

Source: Computed from researcher's raw data.

The result in Table 1 shows that the variables in Ondo West local government Area have varied degrees of linear association among themselves; the correlation coefficients are interpreted in relation to capital budget. Table1 therefore shows that all the capital spending show positive correlation with capital budget except for the value of School buildings (VSB) which is negative (-0.3622). Value of Water provision (VWP) shows the highest correlation (0.95) with capital budget followed by the value of Health facilities (VHF) (0.71) and then VAI which is 0.64 . 
Table 8. Correlation Matrix for Idanre (IDR)

\begin{tabular}{llllll}
\hline & CB & VAI & VWP & VSB & VHF \\
\hline CB & 1.0000 & & & & \\
VAI & 0.6244 & 1.0000 & & & \\
VWP & 0.9595 & 0.5304 & 1.000 & 1.000 & 1.0000 \\
VSB & -0.0142 & -0.4622 & 0.0665 & -0.1870 & \\
VHF & 0.005 & 0.0992 & 0.0577 & & \\
\hline
\end{tabular}

Source: Computed from researcher's raw data.

The result in Table 2 shows that the value of Water provision shows a very high $(0.95)$ positive correlation with capital budget. Just like in Ondo West, the value of School buildings shows a negative relationship with capital budget (CB), while Health facilities show an insignificant (0.005) correlations with capital budget.

Table 9. Correlation matrix for Akoko North West (AKNW)

\begin{tabular}{llllll}
\hline & CB & VAI & VWP & VSB & VHF \\
\hline CB & 1.000 & & & & \\
VAI & -0.1195 & 1.000 & & & \\
VWP & 0.8842 & -0.0451 & 1.0000 & 1.000 & 1.0000 \\
VSB & 0.4724 & 0.2777 & 0.7948 & 0.6396 & \\
VHF & 0.6037 & 0.3613 & 0.5933 & & \\
\hline
\end{tabular}

Source: Computed from researcher's raw data.

The result of correlation analysis for Akoko North West shows that all the capital Spending shows a positive correlation with capital budget in the local government except for the value of Agricultural inputs is negative and insignificant (-0.1195). The value of Water provision shows the highest positive relationship (0.88) with capital budget in the local government.

Table 10. Correlation Matrix for Okitipupa (KTP)

\begin{tabular}{llllll}
\hline & CB & VAI & VWP & VSB & VHF \\
\hline CB & 1.000 & & & & \\
VRAI & 0.9093 & 1.0000 & & & \\
VWP & 0.9149 & 0.7675 & 1.000 & 1.000 & 1.0000 \\
VSB & 0.9144 & 0.8454 & 0.7903 & 0.6049 & \\
VHF & 0.4001 & 0.4781 & 0.1717 & & \\
\hline
\end{tabular}

Source: Computed from researcher's raw data.

From Table 4 all capital spending show positive correlation with capital budget. For example values of Agricultural inputs, Water provision and School buildings are respectively 0.91 .

Table 11. Correlation Matrix for Owo (www)

\begin{tabular}{llllll}
\hline & CBA & VA & VWP & VSB & VHF \\
\hline CB & 1.000 & & & & \\
VAI & 0.2324 & 1.000 & & & \\
VWP & 0.7770 & -0.1880 & 1.000 & 1.000 & 1.0000 \\
VSB & 0.1722 & -0.0165 & 0.4898 & 0.1272 & \\
VHF & 0.6488 & 0.2638 & 0.2532 & & \\
\hline
\end{tabular}

Source: Computed from researcher's raw data.

Correlation coefficients among the capital spending and capital budget allocation are low and positive except for VWP and VHF which are 0.78 and 0.65 respectively. 
Table 12. Correlation Matrix for Odigbo (DGB)

\begin{tabular}{llllll}
\hline & CB & VAI & VWP & VSB & VHF \\
\hline CB & 1.000 & & & & \\
VAI & 0.7478 & 1.000 & & & \\
VWP & 0.2112 & 0.1121 & 1.000 & 1.000 & 1.000 \\
VSB & 0.6419 & 0.4400 & 0.0165 & 0.6442 & \\
VHF & 0.8595 & 0.6592 & 0.0814 & & \\
\hline
\end{tabular}

Source: Computed from researcher's raw data.

The result in Table 6 shows that all the capital spending show positive correlation with capital budget. Relatively the correlation coefficient for value of Water provision (VWP) is lowest (0.21) in the local government, while correlation coefficient for value of facilities (VHF) is the highest (0.86) in the local government.

\subsection{Result of Regression Analysis of Model}

Two micro economic instruments are estimated from the regression results. These are the marginal propensities of capital spending $(\alpha)$ which measures the rate of change in capital budget with respect to change in particular project. The second instance is the coefficient of elasticity $(\mathfrak{E})$ which measures the degree of responsiveness of changes in capital budget to the change in each capital project. The result in Table13 shows the following.

1. In Ondo West, the marginal propensity for Water provision and Health facilities are positive indicating that they are significant while that for Agricultural inputs and school buildings are negative meaning that they are not significant.

2. In Idanre, the marginal propensity for Water provision and Agricultural inputs are positive indicating that they are significant while that for Health facilities and school buildings are negative meaning that they are not significant.

3. In Akoko North West, the marginal propensity for Water provision, School buildings and Health facilities are positive indicating that they are significant while that for Agricultural inputs is negative meaning that it is not significant.

4. In Okitipupa, the marginal propensity for Water provision, Agricultural inputs and school buildings are positive indicating that they are significant while that for Health facilities is negative that is not significant.

5. In Owo, the marginal propensity for Water provision, Agricultural inputs and Health facilities are positive indicating that they are significant while that for School buildings is negative that is not significant.

6. In Odigbo, the marginal propensities for all the four projects are positive. This shows that all the four projects are significantly executed.

Table 13. Marginal Propensities and elasticity's of Capital Budget in the selected Local Government

\begin{tabular}{|c|c|c|c|c|c|c|c|c|c|c|c|c|}
\hline & & VAI & & VWP & & VSB & & VHF & & & & \\
\hline & $\alpha_{0}$ & $\alpha 1$ & $£ 1$ & $\alpha 2$ & $£ 2$ & $\alpha 3$ & $£ 3$ & $\alpha 4$ & $£ 4$ & $\mathrm{R}^{2}$ & F-Stat & Prob \\
\hline NDW & 44.68 & $-1.525^{*}$ & 0.04 & 0.851 & 0.50 & $-2.49 *$ & 0.36 & 5.67 & 0.38 & 0.99 & 166.57 & 0.0000 \\
\hline IDR & $-27.015^{*}$ & 13.02 & 0.31 & 2.16 & 1.20 & $-0.10^{*}$ & 0.011 & $-6.04 *$ & 0.18 & 0.94 & 20.71 & 0.002 \\
\hline AKNW & $-19.71^{*}$ & $-0.114 *$ & 0.12 & 1.797 & 0.89 & 2.124 & 0.07 & 4.85 & 0.54 & 0.81 & 7.594 & 0.01 \\
\hline KTP & $-1739 *$ & 4.70 & 0.13 & 0.82 & 0.33 & 2.60 & 0.94 & $-204 *$ & 0.05 & 0.96 & 45.66 & 0.000 \\
\hline WWW & $-2.567 *$ & 1.22 & 0.24 & 0.76 & 0.53 & $-1.91^{*}$ & 0.28 & 1.84 & 0.63 & 0.95 & 35.07 & 0.0001 \\
\hline DGB & $-21.91^{*}$ & 11.19 & 0.29 & 0.071 & 0.10 & 3.03 & 0.17 & 9.72 & 0.69 & 0.83 & 8.2685 & 0.008 \\
\hline
\end{tabular}

Source: Summary of Regression Results.

Note: $\alpha=$ Measure of marginal propensity; $£=$ Elasticity Coefficient; *= Not significant at $5 \%$ level but significant at lower level.

\section{Conclusion}

From the analysis done above, one can see that water provision is more prevalent and significantly executed in all the local governments. This suggests that water provision is much needed and more acceptable and should therefore form a larger part of the capital projects of the local governments. Majority of our local government in Nigeria are concentrated in the rural areas and are farther away from the state capital. The possibility of access to portable water is very remote and this accounted for the widespread diseases among the rural dwellers. These diseases are water related (water borne) ranging from Cholera, Typhoid and Dysentery to other venereal 
diseases. Government huge capital investment on water provision is therefore believed to be the antidote to better living and good health since health is wealth.

\section{References}

Akpan, N. I. (2005). Government Expenditure and Economic Growth in Nigeria: A Disaggregated Approach. Economic and Financial Review, 43(1), 51- 69.

Durmck, M. J. (2002). Seeking Salvation for Accountability. Paper Presented at the 2002 Annual meeting of the American political science Association, Boston,

Kwanashie, E. L. (2000). The Accountability and Audit of Government (p. 362). Essex, U.K: Manchester University Press.

Nwankwo, T. (2004). The theoretical Approach to Public Budgeting. Nigerian Journal of Public Administration and Local Government (Downloaded from igi.osi/publication/2004/216/101-theorypdf).

Omolehinwa, E. (2005). Government Budgeting and Accounting in Nigeria (p. 385). Lagos: Pumark Nigeria Limited.

Schwartz, S. T., Nikias, A. D., \& Young, R. A. (2008). A Note on Bundling Budgets to Achieve Management Control. Journal of Accounting Education, 27(3), 168-184. http://dx.doi.org/10.1016/j.jaccedu.2010.06.003

Whyne, W. (2003). Cost Accounting and Costing Method (p. 232). UK: Macdonald and Evans Ltd.

World Bank Evaluation Department. (2008). Public sector performance. The critical role of evaluation. Retrieved from www.hmtreasury.gov.uk/doccuments/public on19/12/2009. 